\title{
Subclinical Vitamin D Deficiency and Non- Specific Musculoskeletal Symptoms
}

\section{Subklinik D Vitamini Eksikliği ve Spesifik Olmayan Kas- Iskelet Sistemi Semptomları}

Abdul Baqi Durrani ${ }^{1}$

Khalil Ahmed ${ }^{1}$

Iftikhar Athar Rasool ${ }^{1}$, Ubaidullah Khan Barech ${ }^{1}$

Nusrat Yousaf ${ }^{1}$,

Amir Hamza ${ }^{1}$

${ }^{1}$ Bolan Medical College/Bolan University of Medical and Health Sciences (BUMHS), Quetta

Geliş Tarihi/Received: 5 September 2020 Kabul Tarihi/Accepted: 30 November 2020

Address correspondence to: Khalil Ahmed, Bolan Medical College/Bolan University of Medical and Health Sciences (BUMHS), Quetta

e-mail: chagardii@yahoo.com

\section{ORCID}

Abdul Baqi Durrani

https://orcid.org/0000-0002-7820-886X

Khalil Ahmed

https://orcid.org/0000-0003-0645-5113

Iftikhar Athar Rasool

https://orcid.org/0000-0003-0095-478X

Ubaidullah Khan Barech

https://orcid.org/0000-0002-2004-5770

Nusrat Yousaf

https://orcid.org/0000-0002-2117-219X

Amir Hamza

https://orcid.org/0000-0002-6930-389X

\begin{abstract}
Öz
Amaç: Üçüncü basamak bir hastanede spesifik olmayan kas-iskelet sistemi semptomları olan hastalarda subklinik vitamin $D$ eksikliği sıklığını belirlemektir.

Hastalar ve Yöntem: Kesitsel tipteki bu çalışma, 2018-2019 yılları arasında Quetta, Bolan Medical Complex Hastanesi Tıp Departmanında yapıldı. Yazılı onam alınarak, 20-45 yaş arası toplam 97 hasta çalışmaya alındı. Altı haftadan fazla süren yaygın vücut ağrıları öyküsü olan hastalar bu çalışmaya dahil edildi. Hastaların ayrıntılı öyküleri ve klinik muayeneleri yapılarak veriler kaydedildi. Radyoimmunoassay kiti ile D3 vitamini düzeylerini saptamak için her hastanın kan örneği alındı.

Bulgular: Hastaların ortalama yaşı $34.25 \pm 10.64$ idi. Ortalama semptom süresi $7.71 \pm 0.82$ hafta idi. Erkek / kadın oranı 4: 6 olarak bulundu. Spesifik olmayan kas iskelet sistemi bulguları olan hastaların 72 tanesinde (\%74.20) vitamin D eksikliği tespit edildi.

Sonuç: Spesifik olmayan kas-iskelet sistemi semptomları olan hastalarda subklinik D vitamini eksikliği sıklığı anlamlı derecede yüksek bulundu.
\end{abstract}

Anahtar Kelimeler: Subklinik D vitamini eksikliği, spesifik olmayan kas-iskelet sistemi semptomları, D vitamini

\section{Abstract}

Aim: TTo determine the frequency of subclinical vitamin D deficiency in patients with non specific musculoskeletal symptoms in a tertiary care hospital.

Patients and Methods: This cross-sectional study was performed in Department of Medicine, Bolan Medical Complex Hospital, Quetta between 2018 and 2019 years. A total of 97 patients between 20 and 45 years of age were included the study after written consent. The patients presenting with history of generalized body aches greater than six weeks were included in this study. The detail history was taken and clinical examination was done. Blood sample of each patient were collected to detect the vitamin D3 levels by radioimmunoassay kit.

Results: Mean age of the patients was $34.25 \pm 10.64$ years. Mean duration of symptoms was $7.71 \pm 0.82$ weeks. Male to female ratio was found to be $4: 6$. The frequency of vitamin $D$ deficiency was detected in 72 of the patients with non-specific musculoskeletal symptoms $(74.20 \%)$.

Conclusion: The frequency of subclinical vitamin D deficiency was significantly high in patients with non specific musculoskeletal symptoms

Key words: Subclinical vitamin D deficiency, non-specific musculoskeletal symptoms, vitamin D3
Cite this article as: Durrani AB, Ahmed K, Rasool IA, Barech UK, Yousaf $N$, Hamza A. Subclinical Vitamin D Deficiency and Non-Specific Musculoskeletal Symptoms. Selcuk Med J 2020;36(4): 357-360

"This article is licensed under a Creative Commons Attribution-NonCommercial 4.0 International License_ (CC BY-NC 4.0)" Disclosure: None of the authors has a financial interest in any of the
products, devices, or drugs mentioned in this article. The research was
not sponsored by an outside organization. All authors have agreed to allow
full access to the primary data and to allow the journal to review the data
if requested. 


\section{INTRODUCTION}

Vitamin $D$ insufficiency is a frequent complaints amongst the adult and children especially in developing countries (1). The deficiency of vitamin $\mathrm{D}$ can cause osteomalacia and rickets in adult and children respectively. The clinical manifestations of vitamin $D$ deficiency may include nonspecific backache, joints pain, and generalized body ache presentation in the outpatient department (1-3).

Over the last 10 years, the vitamin $D$ is important for stabilizing immune, reproductive, musculoskeletal, and integumentary system of the human body; have come to the front position $(4,5)$. Badsha et al. (3) have suggested vitamin $D$ deficiency as a possible cause of persistent musculoskeletal ache.

Vitamin D could participate a role in the prevention and treatment of a number of different clinicopathalogical conditions, and deficiency of it is associated with an increased prevalence of cancer, diabetes mellitus, cardiovascular disease; cognitive impairment and multiple sclerosis (6-9). Recently, Kaira et al. (10) found a high incidence of vitamin D deficiency.

A cross-sectional study from India report the prevalence of low vitamin $D$ is $55 \% .10$ in patients presenting with various musculoskeletal complaints. Vitamin D deficiency often presents with nonspecific musculoskeletal symptoms such as pain and weakness. It has been described in previous studies that patients with psychosomatic disorders often were found to have vitamin $D$ deficiency (11).

It has been described by Bhatty et al. (11) that patients with psychosomatic symptoms often were found to have vitamin D deficiency. These symptoms are common presenting complaints in patients across medical specialties. This study has been planned with the objective to determine frequency of vitamin $D$ deficiency in patients having nonspecific musculoskeletal symptoms.

\section{PATIENTS AND METHODS}

This cross-sectional study was conducted at Department of Medicine, Bolan Medical Complex Hospital Quetta from1st July 2018 to 30th June 2019. This population study was based on a total 97 patients between 20 and 45 years of age with subclinical vitamin $D$ deficiency with non specific symptoms. Inclusion criteria included of Patients with history of generalized body aches greater than six weeks. Patients with the following co-morbid conditions determined on previous medical record like chronic kidney disease, osteomalacia, malabsorption syndrome, end stage liver disease and patients on phenytoin or steroid therapy were excluded from the study as all these are effect modifiers, so can produce bias in the study. Complete history was taken for various nonspecific musculoskeletal symptoms such as generalized weakness, backache, body ache, painful aching legs and easy fatigability. A request was made for serum 25 hydroxyvitamin D determinations with riadioimmunoassay kit in the institutional laboratory. A level of serum 25- hydroxyvitamin $D<20 \mathrm{ng} / \mathrm{dl}$ was considered as deficient. During clinical examination of the patients, patients comfort was taken care of. The data was entered and analyzed through SPSS20.

\section{RESULTS}

There were $38(39 \%)$ males and 59(61\%) females patients and male to female ratio was $1: 1.6$. Forty six $(47.40 \%)$ patients were $\leq 35$ years while $51(52.60 \%)$ patients $>35$ years with mean age was $34.25 \pm 10.64$ years. There were $74(76.30 \%)$ patients $\leq 8$ weeks and $23(23.70 \%)>8$ weeks patients were presented with duration of symptoms and mean duration of symptoms was $7.71 \pm 0.82$ weeks. The frequency vitamin D deficiency was detected in 72 (74.20\%) of the patients with non-specific musculoskeletal symptoms (Table 1). When compared the effect of

Table 1. Demographic information of the patients

\begin{tabular}{lll}
\hline Variable & $\mathbf{n}$ & $\%$ \\
\hline Gender & & \\
$\quad$ Male & 38 & 39.0 \\
$\quad$ Female & 59 & 61.0 \\
Age (years) & & \\
$\quad \leq 35$ & 46 & 47.4 \\
$\quad>35$ & 51 & 52.6 \\
Duration of symptoms (weeks) & & \\
$\quad \leq 8$ & 74 & 76.3 \\
$\quad>8$ & 23 & 23.7 \\
$\quad$ Vitamin D deficiency & & \\
$\quad$ Yes & 72 & 74.2 \\
$\quad$ No & 25 & 25.8 \\
\hline
\end{tabular}

Table 2. Comparison of Vitamin D deficiency according to age $(n=97)$

\begin{tabular}{llll}
\hline Age (years) & \multicolumn{2}{l}{$\begin{array}{l}\text { Vitamin D deficiency } \\
\text { Yes }\end{array}$} & Po value \\
\hline$\leq 35$ & $26(26.8 \%)$ & $20(20.6 \%)$ & 0.001 \\
$>35$ & $46(47.4 \%)$ & $5(5.2 \%)$ & \\
\hline
\end{tabular}


Table 3. Comparison of Vitamin D deficiency according to duration of symptoms (weeks)

\begin{tabular}{llll}
\hline $\begin{array}{l}\text { Duration of } \\
\text { symptoms }\end{array}$ & \multicolumn{2}{l}{ Vitamin D deficiency } & P value \\
\hline$\leq 8$ & $61(62.8 \%)$ & No & \\
$>8$ & $11(11.3 \%)$ & $12(13.4 \%)$ & 0.001 \\
\hline
\end{tabular}

Table 4. Comparison of Vitamin D deficiency according to gender

\begin{tabular}{llll}
\hline Gender & \multicolumn{2}{l}{ Vitamin D deficiency } & P value \\
& Yes & No & \\
\hline Male & $33(34 \%)$ & $11(11.3 \%)$ & 0.001 \\
Female & $39(40.2 \%)$ & $14(14.5 \%)$ & \\
\hline
\end{tabular}

age, duration of symptoms and gender on vitamin $D$ deficiency, significant $(P<0.001)$ relationship was observed (Tables 2-4).

\section{DISCUSSION}

It has been suggested that vitamin $\mathrm{D}$ deficiency may be causative etiology of persistent musculoskeletal ache (3). Recently, the authors retrospectively studied records of patients with musculoskeletal or rheumatic symptoms, without evidence of osteomalacia, found a high deficiency of vitamin D (10).

A cross sectional study was conducted at Karachi, revealed $80 \%$ of the patients having vitamin D (11). A retrospective study was done on asymptomatic patient reported $92 \%$ prevalence of low vitamin $D$ level (12).

Vitamin $D$ could contribute a role in the prevention and treatment of a number of different conditions, and deficiency of it is connected with an increased prevalence of cancer, diabetes mellitus, cardiovascular disease; cognitive impairment and multiple sclerosis (6-9).

Vitamin $D$ deficiency is common in all age groups. It is assumed that $1 / 8$ of the world population may have some vitamin $D$ inadequacy, if the value $\leq 30 \mathrm{ng} /$ $\mathrm{mL}$ is labeled as insufficiency of vitamin D level (13).

There are different assay techniques for estimation of vitamin D prevalence worldwide. Although there is no complete data on vitamin D insufficiency and risk factors such as breastfeeding without enough supplementation, darker skin or race, female gender, living in northern latitude, inadequate sun exposure, and winter season (14).

A high prevalence has been reported in children, and teenagers from different countries such as UK15, France (16), Greece (17), Lebanon (18), Turkey (19), and Canada (20).

In the present study frequency of vitamin D deficiency in patients with non-specific musculoskeletal symptoms was found to be 72 (74.20\%) Prevalence rates of vitamin $\mathrm{D}$ deficiency among teenagers have ranged from 0 to $42 \%$, and differences were noted depending on secondary to time of year, autonomy, and member race/ethnicity (21). There was significant effect was observed between age, duration of nonspecific musculoskeletal symptoms and gender with vitamin $\mathrm{D}$ deficiency.

Haagensen et al. (22) reported that teenager girls with anorexia nervosa have low level of vitamin $D$ to support the fat sequestration hypothesis. Low level of Vitamin $D$ in adults is related with higher risk of diabetes mellitus type $(23,24)$, impaired glucose tolerance (25), higher fasting plasma glucose levels (26), and insulin tolerance and dysfunction of B cells, even sometimes in good health individuls (27). Chiu et al. (27) reported that an increment of blood $25(\mathrm{OH})$ D from 10 to $30 \mathrm{ng} / \mathrm{mL}$ may pick up insulin sensitivity by $60 \%$. Simultaneous vitamin D and calcium supplements reduce the risk of being type 2 diabetes mellitus patients (28-30).

There is lower risk of hypertension and myocardial infarction, and diabetic retinopathy in adult with higher level of 25(OH)D reported by Pittas et al. (30) Hypertensive individuals when being exposed with ultraviolet $B$ radiation showed an increase in their $25(\mathrm{OH}) \mathrm{D}$ levels, and reduction in their blood pressure $(31,32)$.

\section{CONCLUSION}

The frequency of subclinical vitamin $D$ deficiency was significantly high in patients with non specific musculoskeletal symptoms.

Conflict of interest: Authors declare that there is no conflict of interest between the authors of the article.

Financial conflict of interest: Authors declare that they did not receive any financial support in this study.

Address correspondence to: Khalil Ahmed, FCPS, Senior Registrar of Medicine, Bolan Medical College/Bolan University of Medical and Health Sciences (BUMHS), Quetta

Telephone: +923355448918

e-mail: chagardii@yahoo.com 


\section{REFERENCES}

1. Holick ME, Chen TC. Vitamin D deficiency: A worldwide problem with health consequences. Am J Clin Nutr 2008;87:S1080-6.

2. Ince $B$, Yildirim MEC, Ismayilzade $M$, et al. Vitamin D and systemic effects of vitamin D Deficiency. Selcuk Med J 2018;34(2): 84-89.

3. Badsha H, Daher M, Ooi Kong K. Myalgiqs or non-specific muscle pain in Arab or Indo-Pakistani patients may indicate vitamin D deficiency. Clin Rheumatol 2009;28:971-3.

4. Khan KA, AKram J, Fazal M. Hormonal actions of vitamin D and its role beyond just being a vitamin: A review article. Int $\mathrm{J}$ Med Sci 2011;3:65-72.

5. Krishnan AV, Trump DL, Johnson CS, et al. The role of vitamin $\mathrm{D}$ in cancer prevention and treatment. Endocrinol Metab Clin North Am 2010;39:401-18.

6. Lee $\mathrm{H}, \mathrm{O}$ 'Keefe $\mathrm{JH}$, Bell $\mathrm{D}$, et al. Vitamin $\mathrm{D}$ deficiency an important, common, and easily treatable cardiovascular risk factor? J Am Coll Cardiol 2008;52:1949-56.

7. Kim MK, II Kang M, Won Oh K, et al. The association of serum vitamin $\mathrm{D}$ level with presence of metabolic syndrome and hypertension in middle-aged Korean subjects. Clin Endocrinol (Oxf) 2010;73:330-8.

8. Garland CF, Gorham ED, Mohr SB, et al. Vitamin D for cancer prevention: Global perspective. Ann Epidemiol 2009;19:46883.

9. Hyatt ML, Delong MR, Kumari M, et al. High prevalence of hypovitaminosis $D$ status in patients with early Parkinson disease. Arch Neural 2011;68:314-9.

10. Kaira S, Kalra B, Khandelwal SK. Vitamin D status in patients with musculoskeletal symptoms in Haryana, India. J Med Nutr Nutraceut 2012;1:50-3.

11. Bhatty SA, Shaikh NA, Irfan M, et al. Vitamin D deficiency in fibromylalgia. J Pak Med Assoc 2010;60:949-56.

12. Zuberi LM, Hague $N$ \& Jabbar A. Vitamin $D$ deficiency in ambulatory patients. J Pak Med Assoc 2008;58:482-4.

13. Holick MF. Vitamin D deficiency. N Engl J Med 2007;357:26681.

14. Hickey L, Gordon CM. Vitamin D deficiency: New perspectives on an old disease. Curr Opin Endocrinol Diabetes 2004;11:1825.

15. Lawson M, Thomas M. Vitamin D concentrations in Asian children aged 2 years living in England: Population survey. BMJ 1999;318:28.

16. Guillemant J, Le HT, Maria A, et al. Wintertime vitamin D deficiency in male adolescents: Effect on parathyroid function and response to vitamin D3 supplements. Osteoporos Int 2001;12:875-9.

17. Nicolaidou P, Hatzistamatiou Z, Papadopoulou A, et al. Low vitamin $D$ status in mother-newborn pairs in Greece. Calcif Tissue Int 2006;78:337-42.

18. Hajj Shahine C, Kizirian A, Tannous R. Hypovitaminosis D in healthy schoolchildren. Pediatrics 2001;107:E53.

19. Pehlivan I, Hatun S, Aydogan M, et al. Maternal vitamin D deficiency and vitamin $D$ supplementation in healthy infants. Turk J Pediatr 2003;45:315-20.

20. Ward LM, Gaboury I, Ladhani M, et al. Vitamin Ddeficiency rickets among children in Canada. CMAJ 2007;177:161-6.

21. Tylavsky FA, Ryder KA, Lyytikainen $A$, et al. Vitamin $D$, parathyroid hormone, and bone mass in adolescents. J Nutr 2005;135:2735S-8S.
22. Haagensen AL, Feldman HA, Ringelheim J, et al. Low prevalence of vitamin $D$ deficiency among adolescents with anorexia nervosa. Osteoporos Int 2008;19(3):289-94.

23. Isaia G, Giorgino R, Adami S. High prevalence of hypovitaminosis $D$ in female type 2 diabetic population. Diabetes Care 2001;24:1496.

24. Scragg R, Sowers M, Bell C. Serum 25-hydroxyvitamin $D$, diabetes, and ethnicity in the Third National Health and Nutrition Examination Survey. Diabetes Care 2004;27:28138.

25. Lind L, Hanni A, Lithell $H$, et al. Vitamin $D$ is related to blood pressure and other cardiovascular risk factors in middleaged men. Am J Hypertens 1995;8:894-901.

26. Ford ES, Ajani UA, McGuire LC, et al. Concentrations of serum vitamin $D$ and the metabolic syndrome among US adults. Diabetes Care 2005;28:1228-30.

27. Chiu KC, Chu A, Go VL, et al. Hypovitaminosis D is associated with insulin resistance and beta cell dysfunction. Am J Clin Nutr 2004;79:820-5.

28. Pittas AG, Lau J, Hu FB, et al. The role of vitamin $D$ and calcium in type 2 diabetes. A systematic review and metaanalysis. J Clin Endocrinol Metab 2007;92:2017-29.

29. Pittas AG, Dawson-Hughes B, Li T, et al. Vitamin D and calcium intake in relation to type 2 diabetes in women. Diabetes Care 2006;29:650-6.

30. Pittas AG, Harris SS, Stark PC, et al. The effects of calcium and vitamin $D$ supplementation on blood glucose and markers of inflammation in nondiabetic adults. Diabetes Care 2007;30:980-6.

31. Aksoy H, Akcay F, Kurtul N, et al. Serum 1,25 dihydroxy vitamin D (1,25(OH)2D3), 25 hydroxy vitamin $D(25(\mathrm{OH})$ D) and parathormone levels in diabetic retinopathy. Clin Biochem 2000;33:47-51.

32. Krause R, Buhring M, Hopfenmuller W, et al. Ultraviolet B and blood pressure. Lancet 1998;352:709-10. 